\title{
The Effects of Budget Deficit on Current Account: Case Study (Palestinian Territories 1996 - 2012)
}

\author{
Khalil Ahmed El-Namrouty ${ }^{1}$, Ahmed Mahmoud Saidam ${ }^{2}$ \\ ${ }^{1}$ Dep't of Economics and Political Science, Islamic University, Gaza, Gaza Strip, Palestinian authority \\ ${ }^{2}$ Economics Development, Islamic University, Gaza, Gaza Strip, Palestinian authority
}

Email address:

knamroty@iugaza.edu.ps (K. A. El-Namrouty), saidam.kytc@gmail.com (A. M. Saidam)

\section{To cite this article:}

Khalil Ahmed El-Namrouty, Ahmed Mahmoud Saidam. The Effects of Budget Deficit on Current Account: Case Study (Palestinian Territories 1996 - 2012). International Journal of Economics, Finance and Management Sciences. Vol. 3, No. 1, 2015, pp. 57-66.

doi: 10.11648/j.ijefm.20150301.17

\begin{abstract}
The researchers examined the effects of public budget deficit on current account in the Palestinian Territories (1996 - 2012). To determine the appropriate economic tools that can be used to reduce the current account chronic deficit, the nature and components of the Palestinian Authority's expenditures and revenues will be studied. Statistical analysis approach is used to illustrate the impact of public budget deficit on current account. This was implemented after checking the stationary of time series by adopting unit root test (Augmented Dickey Fuller). The study findings confirm the positive relationship between public budget deficit and current account in the Palestinian Territories. It appears that an increase in public budget deficit by one USD million will increase the current account deficit by USD 3.08 million. In addition, balance of trade deficit increased by USD 465.3 thousand when the other independent variables such as government and private investments in the model remain constant.
\end{abstract}

Keywords: Public Budget Deficit, Current Account, Fiscal Policy, Palestinian Territories

\section{Introduction}

Economists are concerned about public budget, current account and balance of payments deficit since they became ingrained at the most of economies structure. The deficit effects appeared negatively on economy such as inflation, deterioration of the purchasing power, deterioration in living standards, growth of internal and external debt, increase of the burden of debts services, which cause a strain and drain of reserves and foreign assets. This adversely affects the balance of payments and causes pressure on the international reserves. The current account is an important determinant of the Palestinian economic performance since the volume of foreign trade, goods and services accounts for $97 \%$ of nominal GDP during the study period. (PCPS, 2012) ${ }^{1}$ Palestinian public finance relies mainly on customs, duties and taxes imposed on imports, whereas revenues generated from customs (clearance) account for more than $56 \%$ of the total current revenue. In contrast, the salaries and wages account for $57 \%$ of the total public current expenditure, and there are

1- Palestinian Central Bureau of Statistics, Major National Accounts Variables (1994-2011) at Constant Prices, (Base Year 2004). approximately $90 \%$ of salaries and wages spent on imports (PMA, 2003, and 2012) ${ }^{2}$. This refers to the contribution of government spending which increases imports and degrees of interdependence between the Palestinian public finances and external trade (the largest component of the current account). Lack of government policies led to an increase of imports at the expenses of GDP. That caused the increase of trade balance deficit, larger current account and chronic deficit of the public budget.

\section{Literature Review}

The relationship between fiscal policy and the current account has attracted interest among economists and policymakers alike. For many countries where current account imbalances are especially large, a relevant question has been raised, i.e. to what extent fiscal adjustment can contribute to resolving external imbalances?

In order to study and analyze this phenomenon in the

2- Calculated from data collected by PMA (1996-2002), Department of Research \& Monetary Policy, "Seventh Annual Reports 2002", p.5, 2003, and Data for 2003 up to 2011 from PMA, "Revenues, Expenditures and Financing Sources of PNA Fiscal Operations (Cash Basis)", 2012. 
Palestinian Territories, identify the causality relationship between public fiscal deficit and current account deficit, and analyze the economic impact of these deficits, it was necessary to provide a literature review for this study, which shows various important thoughts related to budget and current account deficits.

While the results have varied among different countries, it may get different results depending on types of econometric techniques used, or depending on the period taken in the same country. (Bahmani and Oskooee, 1989)

It is noted in some countries that there is a relationship from one direction between the budget deficit and current account. Therefore, some countries have a direct positive relation between the budget deficit and the current account deficit, and the direction of the relationship from budget deficit to the current account. These countries are like Iran (Zamanzadeh, and Mehrara, 2011), Jordan (Mdanat, and Shotar, 2009), and Lebanon (Neaime, 2008). This proves the Keynesian proposition hypothesis. In other countries, the relation is negative but in the same direction, which means that every increase in the budget deficit reduces the current account deficit (increase in budget deficit increases the current account). This means that an increase in budget deficit has positive effects on current account. For example, there is a study conducted on 88 non-oil countries (Advanced, emerging and low-income countries) (Abbas, Bouhga-Hagbe, Fatás, Mauro, and Velloso, 2011),.Nevertheless, some other studies have shown that the relationship is also in one direction, but this time the contrary, i.e. the current account is affecting the budget deficit, and not vice versa. This does not match Keynesian proposition. For example, it is found in Kuwait that increase in the budget deficit is caused by a decrease of trade account deficit (the largest component in the current account), (Merza, Alawin, and Bashayreh, 2012), and so do in Pakistan (Rauf, and Qayyum Khan, 2011).

There are several studies conducted in other several countries, or a group of countries, showed that there is a causal relationship between both the budget deficit and the current account. It means that any change in one of those accounts will cause a change in the other account, such as in Libya (Maitah, and Ali, 2010), Saudi Arabia (Kswani, 2001), India, United States (Agrawal, 2011), and several European countries (Magazzino, 2012). This refutes both hypothesis, Ricardian Equivalence (which shows that there is no relationship between both the budget deficit and the current account), and Keynesian proposition. Finally, there are countries such as Egypt (Marinheiro, 2006) that confirmed the Ricardian Equivalence hypothesis. It means there is no impact to any of the budget deficit on the current account or vice versa.

Foreign aid contributed significantly to supporting budget deficit of the Palestinian Authority. It is worth-mentioning that the value of allocated support to the current spending in 2008 budget was USD 1,978 million (USD 1,763 million allocated for current expenditure in the budget). Generally, continuation of the PNA in fiscal consolidation in 2008 and the activation of tax revenue since 2007 led to improve the current revenues. (It increased from USD 1,616 million in 2007 to USD 2,295 million in 2012 , with a growth rate of $7.5 \%$ per year). It led to a decline in the contribution of external support to budget from USD 1,978 million in 2008 to USD 983 million in 2011 (Saleh, p.347, 2011).

\section{Links Between Budget and Current Account Balance in National Accounts}

To clarify the relationship between fiscal deficits and the balance of trade, it is helpful to begin with some national income accounting identities (IMF, 2009).

$$
G D P=y=C+I+G+x-m=C+S+T
$$

Where (y) the Gross Domestic Product "GDP", (C) Aggregate consumption of private sector, (I) Investment expenditure, $(\mathrm{G})$ Government expenditure, (x) Exports from goods and services, (m) Imports from goods and services, (S) Private saving, $(\mathrm{T})$ Government revenues from taxes.

The Gross National Product "GNP" (Y) is determined as the following equation (2):

$$
G N P=Y=G D P+T R_{n e t}
$$

Where $\left(\mathrm{TR}_{\mathrm{net}}\right)$ the net income from external factor,

$$
\begin{aligned}
T R_{\text {net }} & =T R_{\text {in }}-T R_{\text {out }} \\
X & =x+T R_{\text {in }} \\
M & =\mathrm{m}+T R_{\text {out }}
\end{aligned}
$$

Where (X) net inflow to the economy by exports " $\mathrm{x}$ " from goods and services, and income from external production units from the foreign "TRin", (M) net outflow from the economy by imports " $\mathrm{m}$ " from goods and services, and income from internal production units to the foreign "TRout",

The Current Account Balance (CAB) is identified as the following:

$$
C A B=X-M+T R_{n e t}
$$

For the purpose of simplification, it is often assumed that such transfers of the net income from external production do not have a large size in the current account. However, when the external debts of the concerned countries are large and debt service payments are high, the value of net income from external production will be large and negative. The current account shows the size and trend of international loans. When the imports are more than exports, the $(\mathrm{CAB})$ is in deficit, which is financed by borrowing from abroad, the government or the private sector. Therefore, if the current account was in deficit situation, this will increase the net debt by the amount of such a deficit.

According to the identical equation of the National Income in open economy, the National Income (Y) equals (IMF, 2009):

$$
Y=C+G+I+C A B
$$


Moreover, as defined in the Standard National Accounts (SNA) use of the income account:

$$
S=Y-C-G
$$

By substituting the equation (6) in equation (7), the national saving (S) in open economy at general equilibrium condition (Aggregate Supply $=$ Aggregate Demand) is:

$$
S=I+C A B
$$

There should be a distinction between saving decisions in the private and government, as the following:

$$
S=S_{p}+S_{g}
$$

Where $\left(S_{g}\right)$ the government saving, and $\left(S_{p}\right)$ the private saving "that part of income after cut of the taxes not spent for consumption, and it equals:

$$
S_{p}=Y-T-C
$$

While the government saving $\left(S_{g}\right)$ is defined as the difference between the government revenues $(\mathrm{T})$, and government expenditure $(\mathrm{G})$, which takes the form of government procurement, and government transfers (R), so:

$$
S_{g}=T-G-R
$$

From the National Saving definition:

$$
S_{p}=I+C A B-S_{g}
$$

Or,

$$
S_{p}=I+C A B-(T-G-R)
$$

By re-arranging the equation (13)

$$
C A B=\left(S_{p}-I\right)+(T-G-R)
$$

The Current Account Balance $(\mathrm{CAB})=-$ Current Account Deficit $(C A D)$, and the term of $\left(S_{p}-I\right)$ represents the Private Saving Balance (PSB) $=-$ Private Saving Deficit (SD), and Finally the term of $(T-G-R)$ represents the Government Budget Balance $=-$ Government Budget Deficit $(B D)$, then the equation (14) can be showed in the following formula:

$$
C A D=S D+B D
$$

The public budget deficit measures the ability of the government in borrowing the finance of its expenditures. Therefore, the private saving can take three forms:

1. Investment at domestic capital (I)

2. Procurements from the foreigners (CAD)

3. Debits resulting from government expenditures (BD)

The meditation of the equation (15) can note two extremely different situations. First, the assumption that the difference between savings and private investment is stable over time, so the changes in the government budget deficit will be transferred completely to the current account, and thus the twin deficit hypothesis will be concreted. The second case is known as the Ricardian Equivalence Hypothesis, which assumes that the change in the public budget deficit will be fully compensated by the change in private savings. However, the economic reality may be more complicated than those two cases. Verification of the conditions to which the phenomenon of twin deficits must be given to meditate the channels through which government financial deficit will be economically effective (Dornbusch and Fischer, 1994).

According to Keynesian proposition, the public budget deficit can affect private savings, private investment, and current account balance (Vyshnyak, P.7, 2000 ... see next ref.). The final impact of the budget deficit on these three variables depends partially on how to finance the deficit, which considers the possible ways of financing the fiscal deficit at the inadequacy of taxes to meet the increased of the government spending through increasing money supply and collecting seigniorage, domestic borrowing, and external borrowing (Vyshnyak, 2000). On the other hand, Robert Barro 1974 raised the following question: are the government bonds perceived as net wealth by private sector, or not? The answer was No. He concluded that there is equivalence between the impact of issuing government bonds and taxes. Moreover, shifting from tool to another has no real changes on the economy. It is later known as a Ricardian Equivalence Proposition3 (Barro, 1989).

\section{Objectives}

The present study aims to test the tools used by the Palestinian National Authority to treat the deficit in budget and current account. The study also analyzes the public spending and revenues policies adopted by the Palestinian National Authority throughout the study period. The study suggests some conclusions and recommendations that lead to treating the imbalances in both the public budget and the current account in the Palestinian Territories.

\section{Methodology}

Research methodology will depend on the analytical descriptive method and quantitative analytical method (econometric) to study the relationship between budget deficit and current account deficit in the Palestinian Territories, for a period from 1996 to 2012. It is important to mention here that all the data for the study period includes values for the West Bank and the Gaza Strip according to the Palestinian Central Bureau of Statistics (PCBS).

The researchers used time series data (quarterly data) for the Palestinian economy. The data starts from the first quarter

3 - The term of Ricardian, equivalence theorem introduced to macroeconomists by James Buchanan (1976). After Gerald O'Driscoll (1977) documented Ricardo's reservations about this result, some economists have referred to the equivalence finding as being non-Ricardian, but, David Ricardo (1951) was the first to articulate this theory. Therefore, the attribution of the equivalence theorem to Ricardo is appropriate even if he had doubts about some of the theorem's assumptions (Barro, P. 39, 1989) 
of 1996, to the fourth quarter of 2012. Data was collected from the official publications of the Palestinian Central Bureau of Statistics (PCBS), and the Palestinian Monetary Authority (PMA). In addition, the fiscal data (current government expenditures, government investment, government revenues, and international aid) was collected from the Palestinian Ministry of Finance (PMF).

The stationary tested by adopting Augmented Dickey Fuller (ADF) to test the unit root for the variables. Then cointegration test would be performed to ensure that studied variable are integrated by using Johansen cointegration test in order to confirm the existence of an equilibrium relationship at short and long run between twin deficit. Finally, an econometric model will be derived to clarify the relation between current account and public budget.

\section{Economic Performance for Public Budget and Current Account in Palestine}

\subsection{Palestinian Public Budget Deficit (1996-2012)}

Palestinian public budget has suffered from deficit during the study period (1996-2012). According to table (1), in 1996 current deficit began at USD 56.2 million, and it increased in 1997 to reach USD 66.3 million. However, soon that current budget recorded a surplus in 1998 of USD 30.4 million due to the improvement achieved by the management of public revenue to increase domestic revenues, and clearance revenues from Israel. In addition, one of the reasons that contributed to the reduction of the current deficit is the refusal of some donor countries to allocate any resources to support the current budget, starting from 1998 (Abed Al-Razzaq, p. 29, 2002). In terms of the total budget deficit before grants and aid in the same period (1996-1999), it recorded its highest level in 1997, reaching USD 389.5 million, and then it declined until 1999 and reached USD 293.1 million (reduced 14.88\% compared with 1998). It was observed that budget deficit before grants was relatively large compared with the current deficit of the budget because the Palestinian Authority relied entirely on international aid to finance capital spending, and the capital expenditure almost represents a total deficit of budget before grants during the above-mentioned period (El-Jafari, 2002).

Al-Aqsa Intifada in 2000 had devastating effects on the Palestinian economy where domestic revenues declined significantly in 2001 and 2002 , by $71 \%, 69 \%$, respectively compared to 2000 . This decline is due to Israel's barring of transferring entitlements of clearance revenues to the PNA and the inability of domestic taxes. In addition, there was an increase in the rate of unemployment, which led to lower income tax, and it did not stop at this point. The need to spend on relief programs, support the injured and the families of the martyrs and victims increased. (Abu Zaiter, 2012)

In 2003, it was the beginning of financial reform phase, and the current deficit of the budget declined because of increased domestic revenues. However, the deficit remained greater than the deficits in the period from 1996 to 1999, due to expansion in government spending. The decline in the current deficit of the budget continued reduce in the following year (2004), and then the decline in the current deficit reduction was followed by a reduction in total budget deficit before grants and aid, where the last equals with the current deficit (USD 478 million ) in the same year. Capital expenditure faced significant lack. This was a result of reducing the external budget support, where this support amounted to USD 353 million, while in 2003 it was about USD 620 million (in 2004 it was $43 \%$ of 2003 ).

Table (1). Palestinian Public Budget Deficit/Surplus in Cash Basis (1996-2012).

\begin{tabular}{|c|c|c|c|c|c|c|c|c|c|}
\hline & 1996 & 1997 & 1998 & 1999 & 2000 & 2001 & 2002 & 2003 & 2004 \\
\hline Total Net Revenues and Grants (million U.S(\$ & 978.4 & 1087.9 & 1106.5 & 1136.2 & 1449 & 1122 & 987 & 1367 & 1403 \\
\hline Total Net Revenues (Current Revenues) (million \$ U.S( & 653.4 & 795.7 & 868.42 & 901.2 & 939 & 273 & 290 & 747 & 1050 \\
\hline External Support to Budget (Grants and Donations) (million U.S(\$ & 325 & 292.2 & 238.1 & 235 & 510 & 849 & 697 & 620 & 353 \\
\hline Public Expenditures & 927.6 & 1185.2 & 1212.7 & 1194.3 & 1668 & 1435 & 1246 & 1635 & 1528 \\
\hline Current Expenditures and Net Lending & 709.6 & 862 & 838 & 927 & 1199 & 1095 & 994 & 1240 & 1528 \\
\hline Capital Expenditures & 218 & 323.2 & 374.7 & 267.3 & 469 & 340 & 252 & 395 & 0 \\
\hline Budget Current Deficit/Surplus & -56.2 & -66.3 & 30.42 & -25.8 & -260 & -822 & -704 & -493 & -478 \\
\hline Total Deficit/Surplus Before grants and aid & -274.2 & -389.5 & -344.3 & -293.1 & -729.0 & -1162.0 & -956.0 & -888.0 & -478.0 \\
\hline Growth of Total Deficit/Surplus Before grants and aid (\%) & & 42.0 & -11.6 & -14.9 & 148.7 & 59.4 & -17.7 & -7.1 & -46.2 \\
\hline Total Deficit/Surplus After grants and aid & 50.8 & -97.3 & -106.2 & -58.1 & -219.0 & -313.0 & -259.0 & -268.0 & -125.0 \\
\hline Growth of Total Deficit/Surplus After grants and aid (\%) & & -291.5 & 9.1 & -45.3 & 276.9 & 42.9 & -17.3 & 3.5 & -53.4 \\
\hline Total Deficit/Surplus Before grants and aid/Nominal GDP \% & 8.1 & 10.5 & 8.7 & 7.0 & 17.4 & 29.8 & 27.9 & 23.1 & 11.4 \\
\hline
\end{tabular}

Table (1). (Continue)

\begin{tabular}{|c|c|c|c|c|c|c|c|c|}
\hline & 2005 & 2006 & 2007 & 2008 & 2009 & 2010 & 2011 & 2012 \\
\hline Total Net Revenues and Grants (million U.S(\$ & 2006 & 1741 & 2938 & 3757.8 & 2950.4 & 3204 & 3160 & 3270.1 \\
\hline Total Net Revenues (Current Revenues) (million \$ U.S( & 1370 & 722 & 1616 & 1779.7 & 1548.6 & 1927.7 & 2177 & 2360.7 \\
\hline External Support to Budget (Grants and Donations) (million U.S(\$ & 636 & 1019 & 1322 & 1978.1 & 1401.8 & 1277 & 983.3 & 909.4 \\
\hline Public Expenditures & 2281 & 1707 & 2877 & 3463 & 3106 & 3258.3 & 3245.1 & 3135.8 \\
\hline Current Expenditures and Net Lending & 1994 & 1426 & 2567 & 3273 & 2920 & 2983.2 & 2950.6 & 2966.5 \\
\hline
\end{tabular}




\begin{tabular}{|c|c|c|c|c|c|c|c|c|}
\hline & 2005 & 2006 & 2007 & 2008 & 2009 & 2010 & 2011 & 2012 \\
\hline Capital Expenditures & 287 & 281 & 310 & 190 & 186 & 275.1 & 294.5 & 169.3 \\
\hline Budget Current Deficit/Surplus & -624 & -704 & -951 & -1493.3 & -1371.4 & -1055.5 & -773.6 & -605.8 \\
\hline Growth of Current Deficit/Surplus (\%) & 30.5 & 12.8 & 35.1 & 57.0 & -8.2 & -23.0 & -26.7 & -21.7 \\
\hline Total Deficit/Surplus Before grants and aid & -911.0 & -985.0 & -1261.0 & -1683.3 & -1557.4 & -1330.6 & -1068.1 & -775.1 \\
\hline Growth of Total Deficit/Surplus Before grants and aid (\%) & 90.6 & 8.1 & 28.0 & 33.5 & -7.5 & -14.6 & -19.7 & -27.4 \\
\hline Total Deficit/Surplus After grants and aid & -275.0 & 34.0 & 61.0 & 294.8 & -155.6 & -54.3 & -85.1 & 134.3 \\
\hline Total Deficit/Surplus Before grants and aid/Nominal GDP \% & 19.7 & 21.3 & 24.3 & 26.9 & 23.2 & 16.0 & 12.2 & 8.4 \\
\hline
\end{tabular}

Source: Collected data from following resources:

- $\quad$ Palestinian Central Bureau of Statistics, Major National Accounts Variables for the Years 1994-2011 at Constant Prices: 2004 is the Base Year

- Data for 2012 was from Palestine Economic Policy Research Institute (MAS), 2013, "Economic and Social Monitor, Volume 31

- $\quad$ PMA, "Revenues, Expenditures and Financing Sources of PNA Fiscal Operations (Cash Basis)", 2012

After 2006, Israel stopped paying dues of clearance, and also the donor countries stopped to deal with the PNA government, which led to the aggravation of the financial problem making the total deficit before grants and aid in the 2007 about USD 1261 million. In addition, this is the largest deficit of the budget for the PNA since its arrival in 1994. This deficit was about $24.3 \%$ of GDP. (MAS, Economic and Social Monitor, Volume 12, 2008).

With the generous increase in external support, the government was able to reduce the deficit and turn it into a surplus equivalent to $4.2 \%$ of GDP, after total revenues (domestic and foreign) in 2008 exceeded total expenditure by about USD 295 million. These amounts were used to reduce part of the PA's debt to the banks operating in the Palestinian Territories by about USD 227 million. About USD30 million of those amounts are paid already for the banks, and the amount of USD197 million returned as income from the Palestinian Investment Fund to repay the debt of the PNA included under net financing from local banks. Those debts declined from 483 million USD in 2006 to 422 million USD in 2007 , and then they returned to increase to reach at the end of 2008 about 534 million USD (PMA, Annual Report 2008, p. 56-58, 2009).

The years 2010 and 2012 showed a rise in net domestic revenues from USD 1.54 billion in 2009 and to USD 2.36 billion in 2012 (an increase of $15.3 \%$ per year). In addition, public spending reduced during that period for minor proportions, and this contributed to reducing the current budget deficit from USD 1.3714 billion in 2009 to USD 605.8 million in the year 2012 (reduced by $23.8 \%$ annually). In spite of this improvement, foreign aid for supporting budget is still very important in financing current expenditures. Nevertheless, deficit in total budget is still, even after grants and aid. This financial gap has been bridged by borrowing from local banks and through increasing domestic arrears (MAS, Round Table Discussion (2), p. 11, 2012).

\subsection{Palestinian Current Account}

The Palestinian Territories suffered from deficit in the current account during the study period (1996-2012), but this deficit fluctuated during that period, and the reason is certainly due to a change in one of the main components of the current account (Trade Balance, balance of income and current transfers). When analyzing the data contained in table (2), the current account deficit since the beginning of (1996) reached to USD 1131.2 million, and the deficit continued to increase to USD 1284.6 million in 1999 (increasing at a rate of $4.4 \%$ per year). The current account deficit accounted for $31.8 \%$ of GDP during the period 1996-1999.

Soon this deficit decreased in 2000 to 990.3 million USD (23\% reduction of the deficit in 1999). One of the most important reasons for this deficit drops is a decline in the deficit in the trade balance, in addition to the increase of surplus of current transfers account, where the amount of such transfers is USD 638.6 million compared to USD 373.5 million in 1999. The current account deficit continued to decline until it reached to USD 436.4 million in 2002 (decline by $56.3 \%$ from 2001 ). Therefore, the current account deficit forms about $12.7 \%$ of GDP. The main reason is the decline in deficit of balance of trade $(21.8 \%$ reduction from 2001), and the reason is due to a significant decline in good imports (decreased by $24.8 \%$ in 2002 compared to 2001). In addition, increasing in surplus of the current transfers account contributed to this decrease in the current account deficit.

Table (2). Growth of Current Account Components in Palestinian Territories (1996-2012).

\begin{tabular}{|c|c|c|c|c|c|c|c|c|c|c|c|c|c|c|c|c|c|}
\hline & 1996 & 1997 & 1998 & 1999 & 2000 & 2001 & 2002 & 2003 & 2004 & 2005 & 2006 & 2007 & 2008 & 2009 & 2010 & 2011 & 2012 \\
\hline $\begin{array}{l}\text { CURRENT } \\
\text { ACCOUNT }\end{array}$ & 1131.2 & -122 & $3-119$ & -128 & -990.3 & -997.9 & -436.4 & -915.1 & -1516 & -115 & 2. & -417.3 & 764.4 & -712.5 & -690.9 & -242 & 6 \\
\hline Trade Account & -22 & & & & & 240 & 104 & 6206 & $2-2$ & 2 & 2 & $4-35$ & $3-35$ & 38 & $2-3$ & $9-49$ & 6.5 \\
\hline Goods & -2073.6 & -2122.6 & $6-1$ & $2-2$ & $2-21$ & -1999.4 & $4-147$ & -175 & -233 & -2680 & -2795 & -317 & $2-3$ & 350 & $4-36$ & $8-46$ & $4-4884$ \\
\hline Exports & 514.7 & 594.5 & 528.8 & 527.4 & 539.5 & 394.8 & 327.4 & 368 & 400.7 & 434.7 & 450.4 & 646.5 & 668.4 & 631.3 & 666.1 & 1524.9 & 1249.6 \\
\hline Imports & 2588.4 & 2717.2 & 2510 & 2675.6 & 2721.5 & 2394.2 & 1800.5 & 2119.9 & 2736.5 & 3114.7 & 3245.4 & 3824.7 & 3902.8 & 4135.7 & 4318.9 & 6188.3 & 6133.6 \\
\hline ervices & -143.7 & -221.5 & -284.5 & -263.7 & -75.2 & -494.7 & -476.5 & -314.3 & -360.9 & -221.2 & -300.4 & -373.1 & -340.3 & -351.8 & -312.1 & -261 & -382.5 \\
\hline Imports & 436.8 & 503.1 & 450.4 & 466.7 & 548.2 & 674.8 & 673.3 & 573.3 & 601.3 & 503.7 & 560.3 & 742.6 & 836.4 & 931.1 & 1142.8 & 948.1 & 1058.2 \\
\hline
\end{tabular}




\begin{tabular}{|c|c|c|c|c|c|c|c|c|c|c|c|c|c|c|c|c|c|}
\hline & 1996 & 1997 & 1998 & 1999 & 2000 & 2001 & 2002 & 2003 & 2004 & 2005 & 2006 & 2007 & 2008 & 2009 & 2010 & 2011 & 2012 \\
\hline Income & 578 & 651.2 & 718.7 & 753.8 & 628.3 & 523 & 417.1 & 480.4 & 446.5 & 574.2 & 691.9 & 765.7 & 919.2 & 876.2 & 1098.1 & 1148.9 & 1072.4 \\
\hline Receipts & 598.2 & 683.4 & 748.2 & 775.6 & 670.7 & 541.7 & 428.2 & 482.6 & 478.7 & 609.4 & 700.5 & 773.6 & 922.6 & 955.9 & 1213.2 & 1207.6 & 1174.1 \\
\hline $\begin{array}{l}\text { Compensation of } \\
\text { employees }\end{array}$ & 491 & 560.9 & 681.7 & 705.9 & 581.1 & 400 & 337.2 & 427.7 & 421.4 & 486.7 & 579.2 & 598.5 & 746.2 & 831.1 & 1077.4 & 1117.4 & 1051.2 \\
\hline $\begin{array}{l}\text { Investment } \\
\text { income }\end{array}$ & 107.2 & 122.4 & 66.5 & 69.7 & 89.6 & 141.7 & 91 & 54.9 & 57.3 & 122.6 & 121.3 & 175.1 & 176.4 & 124.7 & 135.8 & 90.2 & 122.8 \\
\hline Payments & 20.2 & 32.2 & 29.5 & 21.8 & 42.4 & 18.6 & 11.1 & 2.2 & 32.2 & 35.2 & 8.6 & 7.9 & 3.4 & 79.7 & 115.1 & 58.7 & 101.7 \\
\hline Inflows & 598.3 & 591.4 & 433.7 & 458.8 & 761.4 & 1076.6 & 1195.6 & 923.9 & 895.3 & 1299.4 & 1623 & 2505.5 & 3572.8 & 2502 & 2476.5 & 1616.8 & 1649.6 \\
\hline $\begin{array}{l}\text { General } \\
\text { government }\end{array}$ & 336.9 & 260.9 & 189.5 & 236.1 & 243.5 & 329.8 & 419.4 & 667.1 & 535.6 & 957.8 & 1101.4 & 1053 & 1977.8 & 1484.3 & 1214.2 & 727.5 & 520.2 \\
\hline $\begin{array}{l}\text { To the private } \\
\text { sector }\end{array}$ & 261.4 & 330.5 & 244.2 & 222.7 & 517.9 & 746.8 & 776.2 & 256.8 & 359.8 & 341.6 & 521.6 & 1452.4 & 1595 & 1017.7 & 1262.3 & 889.3 & 1126.4 \\
\hline Outflows & 90.1 & 121.7 & 76.8 & 85.3 & 122.7 & 103.4 & 99.5 & 253.2 & 161.2 & 124.5 & 132.4 & 137.2 & 152.9 & 234.5 & 300.6 & 270.1 & 270.2 \\
\hline
\end{tabular}

Source: Collected data depending on the following sources

- $\quad$ Data for years 1996-1997: Palestine Monetary Authority, "Balance of payments 1995-2011

- Data for years 1998-2012: Palestinian Central Bureau Statistics, " Palestinian Balance of Payments in Palestinian Territory 1998 - 2011

In the period 2003-2005 (the period of financial reform), the current account deficit rose up to USD 1516 million 2004 (an increase of $65.7 \%$ from 2003 due to the large increase in the trade deficit). Nevertheless, the current account deficit significantly reduced by average rate of $6 \%$ per year from 2006-2012. It is worth mentioning that the reason for the decline in the current account deficit is a significant increase in the current transfers account. The current account recorded a surplus in 2008 for the first time in the Palestinian Territories by USD 764.4 million. The main reason for this is the large increase in the current transfers where current transfers in 2008 increased by USD 1.05 billion compared with 2007 (it was USD 3.4199 billion in 2008). However, in the period 2011-2012, the current account deficit increased significantly up to USD 2814.8 million in 2012. This is the highest deficit ever witnessed in the Palestinian Territories during the study period, and it is due to the significant increase in the trade deficit, in addition to a decline in the surplus of income and current transfer's accounts.

\section{Statistical Analysis and Results}

The study model will be applied by using quarterly time series data to the Palestinian Territories for the period (1996-2012), and the data is related to several economic variables, which are parts of the public budget components such as revenues, expenses and aid, others refer to the level of prices, and others reflect the political situation. These variables have been described as follows:

\subsection{Dependent Variable (Current Account) Data}

The researchers conduct two regression models; first using a Current Account (CA) as a dependent variable, and the second group using a Trade Account (TA) as a dependent variable, because a trade account is considered as a major component of current account and trade account is considered an important and truthful measure for economy. Other components of current account such as income and current transfers are considered unstable components, because they almost follow the political situation and stability.
1. Current Account (CA): The data for current account of the Palestinian Territories is taken from the Palestinian Central Bureau of Statistics (PCBS) as annual data for the period 1996-2012.

2. Trade Account: The data for trade account is taken as quarter data from PCBS.

\subsection{Independent Variables}

Private Investment (IP) is taken from PCBS for the period from 1996 to 2012.

Government Investment (IG) data for the Palestinian Territories were available on an annual basis from the PCBS for the period from 1996 to 2012 .

The data for the group of variables related to the public budget (Government Current Expenditure and Net Lending (CENL), Government Current Revenues (CR), and aid) is available on a quarterly basis from the Palestinian Ministry of Finance.

\section{Econometrics Models}

1. The model of dependent variable the Current Account (CA):

$$
C A_{t}=\alpha_{0}+\beta_{1} A I D_{t}+\beta_{2} C R_{t}+\beta_{3} C E N L_{t}+\beta_{4} I G_{t}+\beta_{5} I P_{t}+\varepsilon_{t}
$$
Equ.1

2. The model of dependent variable the Trade Account (TA):

$$
T A_{t}=\alpha_{0}+\beta_{1} A I D_{t}+\beta_{2} C R_{t}+\beta_{3} C E N L_{t}+\beta_{4} I G_{t}+\beta_{5} I P_{t}+\varepsilon_{t}
$$

Equ. 2

\subsection{Unit Root Test Results Using ADF}

Data variables were non-stationary at its level except (IG). After making the same test for the variables at the first difference, the results show that all variables become stationary at the first difference at Sig level 5\% except (IP) and (TA) still non-stationary. Finally, all the variables were stationary at second level. This means that all variables in 
studied time series are integrated of second order $\left[Y_{t} \sim \mathrm{I}(2)\right]$ cointegration test between the variables time series. and this is considered a good indicator for adopting

Table (3). Unit root test by using Augmented Dickey Fuller (ADF) test.

\begin{tabular}{llllllll}
\hline \multirow{2}{*}{ P-value } & Variables & & & & \\
\cline { 2 - 8 } & CA & TA & CENL & CR & AID & IP & IG \\
\hline Level & 0.7133 & 0.9962 & 0.7925 & 0.5455 & 0.5113 & 0.2065 & 0.0463 \\
1st Difference & 0.0000 & 0.0570 & 0.0000 & 0.0000 & 0.0000 & 0.0849 & 0.0275 \\
2nd Difference & 0.0213 & 0.0000 & 0.0000 & 0.0000 & 0.0000 & 0.0000 & 0.0000 \\
\hline
\end{tabular}

\subsection{Johansen Cointegration Test}

The researcher need to check if all variables are cointegrated for each model, i.e. if a linear combination of these variables are stationary. The regression on the levels of these variables would be meaningful then it will not miss any valuable long-term information. Johansen Cointegration test adopted, whose test assumption is linear deterministic trend in the data for the purposes of this analysis. The results of this test are displayed in table (4).
Regarding the results for equation no. 1, Table 4 shows the rejection of the null hypothesis of no cointegration at $5 \%$ significance level, and it shows there are at least five integrating equations at the 0.05 level.

The data of equation 2 shows the rejection of the null hypothesis of no cointegration at $5 \%$ significance level, and it also shows there are at least four integrating equations at the 0.05 level.

Table (4). Cointegration test by using Johansen Technique.

\begin{tabular}{|c|c|c|c|}
\hline Equation \# & Hypothesized No. of Cointegration Equations & P- value at Sig Level $=5 \%$, of Trace & $\begin{array}{l}\text { P- value at Sig Level = 5\%, of Max. } \\
\text { Eigenvalue }\end{array}$ \\
\hline \multirow{8}{*}{ Equation 1} & None & 0.0000 & 0.0000 \\
\hline & At most 1 & 0.0000 & 0.0000 \\
\hline & At most 2 & 0.0000 & 0.0004 \\
\hline & At most 3 & 0.0000 & 0.0070 \\
\hline & At most 4 & 0.0000 & 0.0018 \\
\hline & At most 5 & 0.0038 & 0.1269 \\
\hline & At most 6 & 0.0082 & 0.0613 \\
\hline & At most 7 & 0.0093 & 0.0093 \\
\hline \multirow{7}{*}{ Equation 2} & None & 0.0000 & 0.0000 \\
\hline & At most 1 & 0.0000 & 0.0000 \\
\hline & At most 2 & 0.0000 & 0.0007 \\
\hline & At most 3 & 0.0000 & 0.0015 \\
\hline & At most 4 & 0.0037 & 0.4189 \\
\hline & At most 5 & 0.0028 & 0.1507 \\
\hline & At most 6 & 0.0044 & 0.0265 \\
\hline
\end{tabular}

Regression analysis for variable affecting the current account (CA)

Table (4) shows the regression coefficients and their P-values. All independent variables are statistically significant except for CR since all P-values are less than 0.05 level of significance. In addition, based on t-statistic, the most significant variable is the private investment in Palestine. The estimated regression equation is:

$$
\begin{gathered}
C A=-1.7251-0.0774 C R-0.2206 C E N L+0.2474 A I D \\
+3.1921 I G-5.9999 I P
\end{gathered}
$$

\begin{tabular}{|c|c|c|c|c|}
\hline \multicolumn{5}{|c|}{ Dependant Variable: CA } \\
\hline Variables & Coefficient & Std. Error & t-Statistic & Prob. \\
\hline $\mathrm{C}$ & -1.7251 & 12.622 & -0.136 & 0.891 \\
\hline $\mathrm{CR}$ & -0.0774 & 0.129 & -0.596 & 0.553 \\
\hline CENL & -0.2206 & 0.096 & -2.295 & 0.025 \\
\hline AID & 0.2474 & 0.076 & 3.229 & 0.002 \\
\hline IG & 3.1921 & 1.107 & 2.884 & 0.005 \\
\hline IP & -5.9999 & 1.028 & -5.836 & 0.000 \\
\hline
\end{tabular}

Table (5). Regression coefficients for CA (Palestine).
$\mathrm{R} 2=0.5208$, Adjusted R2 $=0.4808$, Durbin-Watson stat $=2.0226$, Prob. (F-statistic $)=0.00000$

\subsection{Assessing Classical Assumption for Model (Ordinary Least Square (OLS) Assumption)}

- The graph at annex-1shows the linearity pattern for the model independent variables.

- The error term has a zero population that is (1.25E-14), which is very small and near to zero, and by using the same procedure for equation no. 1. P-value was 1.0

- Covariance test for the error term with explanatory variables (CR, CENL, AID, IG, and IP) shows P-value = 1.000 for each explanatory variable with error term. This means rejection of null hypothesis (all explanatory variables are correlated with the error term), and acceptance of the alternative hypothesis that all explanatory variables are uncorrelated with the error term.

- Durbin-Watson value is 2.022, which means there is no serial correlation problem. 
- The variance inflation factor coefficient diagnostic shows that all VIF of coefficient are lower than $5(\mathrm{CR}=$ $1.27, \mathrm{CENL}=1.677, \mathrm{AID}=1.55, \mathrm{IG}=1.07$, and $\mathrm{IP}=$ $1.15)$, which means there is no multicollinearity problem in the estimated model.

- Using White test for heteroskedasticity shows P-value of Chi-Square is 0.3655. Thus, we accept the null hypothesis, which states that the error term has constant variance (no heteroskedasticity).

- The high number of observations (68 observations) can indicate that the error term is normally distributed.

- $\quad$ Statistical results show that $48.08 \%$ of the variation of Palestinian current account explained by independent variables is included in above-mentioned model (CR, CENL, AID, IG, and IP). High t-statistic value for private investment shows the largest negative effect on current account. Therefore, an increase in private investment by USD one million will increase the current account about USD 6 million. This result is caused because the nature of the private investment in Palestine is oriented to invest in importing consumption goods. This causes the deficit of trade account (largest component of current account). The current revenues CR have negative effects because most of those revenues (56.55\% of current revenues) come from clearance revenues (taxes on goods shipped from Israel to the West Bank and Gaza). The government investment (IG) has positive role in increasing current account because the public investment is oriented for improvement of infrastructure sectors. In the beginning of the Al-Aqsa Intifada in 2000, the foreign aid reached to USD 510 million (75.7\% of government revenues), compared with the previous year where the total aid to support budget was USD 235 million. In addition, the aid allocated to support public budget reached to USD 1.978 billion in2008. However, it is clearly noted that support has dropped significantly in the stable situations; for example, in the beginning of the economic reform period (2004) to the Palestinian National Authority institutions where the external support to budget was USD 353 million.

\subsection{Regression Analysis for Variable Affecting the Trade Account (TA)}

Table (6). Regression coefficients for CA (Palestine).

\begin{tabular}{|c|c|c|c|c|}
\hline \multicolumn{5}{|c|}{ Dependant Variable: TA } \\
\hline Variables & Coefficient & Std. Error & t-Statistic & Prob. \\
\hline $\mathrm{C}$ & -0.181421 & 1.746499 & -0.103877 & 0.9176 \\
\hline IG & 0.651224 & 0.149519 & 4.355466 & 0.0000 \\
\hline IP & -1.682535 & 0.134007 & -12.55557 & 0.0000 \\
\hline
\end{tabular}

$\mathrm{R}^{2}=0.7232$, Adjusted $\mathrm{R}^{2}=0.7145$, Durbin-Watson stat $=2.5216$, Prob.(F-statistic) $=0.00000$

Statistical results at table (5) show that $71.45 \%$ of the variation of Palestinian current account explained by independent variables is included in above-mentioned model (IG, and IP). High t-statistic value for private investment shows the largest negative effect on current account. The components of public budget CR, CENL, and aid are not statically significant at $5 \%$ level. Therefore, they are eliminated from the model. The estimated regression equation is:

$$
T A=-0.1814+0.6512 I G-1.5825 I P
$$

\subsection{Assessing Classical Assumption for Model (Ordinary Least Square (OLS) Assumption)}

- The graph at annex-1 shows the linearity pattern for the model independent variables.

- The error term has a zero population that is (5.99E-16), which is very small and is near to zero, and by using the same procedure for equation no. 1. P-value was 1.0

- Covariance test for the error term with explanatory variables (IG, and IP) shows P-value $=1.000$ for each explanatory variable with error term. This means rejection of null hypothesis (all explanatory variables are correlated with the error term) and acceptance of the alternative hypothesis. This also means that all explanatory variables are uncorrelated with the error term.

- Durbin-Watson value is 2.5216, which means there is no serial correlation problem.

- The variance inflation factor coefficient diagnostic shows that all VIF of coefficient are lower than 5 ( $\mathrm{IG}=$ 1.02 , and IP $=1.02$ ), which means there is no multicollinearity problem in the estimated model.

- Using White test for heteroskedasticity shows P-value of Chi-Square is 0.4630 . This means acceptance of null hypothesis which states that the error term has constant variance (no heteroskedasticity).

- The high number of observations (68 observations) can indicate that the error term is normally distributed.

Fiscal and trade policies adopted in the Palestinian Territories during the study period led to deepen both the deficit in the public budget of the Palestinian National Authority and the trade account (the largest component of the current account). Whereas the public spending was not directed to serve economic growth, but it was sometimes justified by the worse political and economic conditions witnessed by the Palestinian Territories during that period, which began in 2000 by Al-Aqsa Intifada and ended with the Israeli war on Gaza in 2012. Excessive reliance on worker remittances revenues of Palestinian workers in Israel has led to increased economic dependence on Israeli economy policies. This makes the Palestinian economy highly susceptible to shocks and external economic volatility. This is observed during the Al-Aqsa Intifada. The main cause of trade account deficit is the continuing weakness of the Palestinian productive base where the goods exports amounted to $11.75 \%$ of GDP, and total exports (goods and services) did not exceed $18.8 \%$ of GDP during the study period.

Government investment (IG) has positive coefficient sign. This means an increase of government investment reduces the deficits of current and trade accounts. The econometric study 
shows an increase in government investment (IG) by USD one million. This will increase the current account (CA) by USD 3.218 million, or an increase the trade account (TA) by USD 651.2 thousands when all other independent variables remain constant. However, the government usually invests in projects that make economics externalities such as infrastructures projects (roads, water and sewage networks, electricity, education, health, and other projects that are not made by private sector). The study of (Abu Muatafa, 2009) in the Palestinian Territories through studying the effect of external financing to the public budget shows that capital spending is insignificant with budget deficit.

The private investment (IP) has the largest effect on current and trade accounts, and it has negative coefficient sign at the estimated model. This means an increase in private investment leads to high increase in deficits of current and trade accounts. The econometric study shows an increase in private investment (IP) by USD one million. This will increase deficit in current account (CA) by USD 5.999 million, or it will increase the deficit of trade account (TA) by USD 1.682 million when all other independent variables remain constant. The result of this study was consistent with (Munshed, 2005) for Egypt, Tunisia, and Morocco, and (Saeed, and Arshad Khan, 2012) in Pakistan, and (Altintas and Taban, 2011) in Turkey. The situation in Palestine differs. This appears by the coefficient sign of private investment at an econometric study. This happened as result of the nature of private investment in the Palestinian Territories, where most of Palestinian producers for food industry, pharmaceutical industry, shoes, clothes, and other industries transform to an importer for those types of products either from Israel or through Israel, especially Southeast Asian Nations.

\section{Conclusions and Recommendations}

During the study period, the average growth of nominal government spending is $12.26 \%$ per year. However, the average real growth rate for this spending did not exceed $6.9 \%$ per year. While the average growth rate of government spending per capita was $4.21 \%$ annually, government capital spending suffered a significant decline during the years of the study. Part of this is due to unstable political and economic situation witnessed by the Palestinian Territories (Al-Aqsa Intifada, the political division, and the wars on Gaza in 2008 and 2012). It is noticeable that the government capital expenditures were growing significantly during the establishment period (1994 to 1999). Current revenues depend highly on clearance revenues (Tariffs of Palestinian imports through Israeli ports). The average of clearance revenues was about $56.55 \%$ of the current revenues, while domestic revenues (tax and non-tax revenues) accounted for $43.45 \%$ of the value of current revenues. The absence of Palestinian national currency contributed to significant limitation in monetary policies that may be taken by the Palestinian Authority to reduce the public deficit.

Deficit in the trade account is much larger than the current account deficit. The reason for the decline in the current account deficit in the Palestinian Territories is the current transfers' item, which represents the international aid, grants, and donation. The current account recorded a surplus in 2008 by USD 764.4 million because of the large increase in current transfers to the Palestinian National Authority, which is a net current transfer that amounted to USD 3.42 billion. The main cause of trade account deficit is the continuing weakness of the Palestinian productive base where the goods exports amounted to $11.75 \%$ of GDP. The low capital spending leads to shortage and weaknesses in infrastructure and government development projects. Therefore, this discourages the private investment in productive projects. Thus, the private investment transfers to the projects depend on imports, which harm the trade deficit in the Palestinian Territories.

Based on the study results, it is recommended that, (a) Distribute the public current revenues between current spending and capital (investment) spending in order to increase the proportion of capital spending to public expenditures. In other words, the PNA should increase the share of development expending. (b) Prepare a comprehensive development plan for the infrastructure in the Palestinian Territories, and start to implement it using current revenue as much as possible and reduce dependence on external support. (c) Utilize the external support to the budget as much as possible only in development projects and reduce the amounts of aid allocated for relief projects. (d) Support export promotion strategy in industries such as food, agriculture, clothes, shoes, wooden and plastic industries, and other industries. (e) Follow-up private projects and make sure to perform the quality control system to ensure that projects can be marketed locally and to ensure they can be competitive externally. In addition, ensure the sustainability of private sector projects by working on development of domestic industries, according to total quality management criteria.

Table (7). Data of econometric models variables.

\begin{tabular}{lllllll}
\hline Obs & CA & CR & CENL & AID & IP & IG \\
\hline 1996 & -1131.2 & 864.8 & -1131.2 & 325 & 806.9 & 403.5 \\
1997 & -1223.3 & 773.7 & -1223.3 & 292.2 & 882.6 & 401.2 \\
1998 & -1190.2 & 807.8 & -1190.2 & 238.1 & 937.6 & 468.8 \\
1999 & -1284.6 & 714.4 & -1284.6 & 235 & $1,143.1$ & 663.6 \\
2000 & -990.3 & 1009.7 & -990.3 & 510 & 861.1 & 556.1 \\
2001 & -997.9 & 1003.1 & -997.9 & 849 & 711.8 & 415.4 \\
2002 & -436.4 & 1565.6 & -436.4 & 697 & 498.1 & 385.2 \\
2003 & -915.1 & 1087.9 & -915.1 & 620 & 606.8 & 475.1 \\
2004 & -1516 & 488 & -1516 & 353 & 687.7 & 294.7 \\
2005 & -1152.2 & 852.8 & -1152.2 & 636 & 691.8 & 565.3 \\
2006 & -921.9 & 1084.1 & -921.9 & 1019 & 824.3 & 569.3 \\
2007 & -417.3 & 1589.7 & -417.3 & 1322 & 906.7 & 635.5 \\
2008 & 764.4 & 2772.4 & 764.4 & 1978.1 & 683.2 & 478.8 \\
2009 & -712.5 & 1296.5 & -712.5 & 1401.8 & 710.9 & 498.3 \\
2010 & -690.9 & 1319.1 & -690.9 & 1277 & 849.7 & 595.6 \\
2011 & -2429.6 & -418.6 & -2429.6 & 983.3 & $1,387.5$ & 459.2 \\
2012 & -2814.8 & -802.8 & -2814.8 & 909.4 & $1,467.1$ & 366.9 \\
\hline
\end{tabular}




\section{References}

[1] Abdur Rauf, and Abdul Qayyum Khan (2011) "An Empirical Study to Find the Relationship between Trade Deficit and Budget Deficit in Pakistan", Academic Research International, Pakistan, Volume: 1, issue 3, P. 36-46. http://www.savap.org.pk/journals/ARInt./Vol.1(3)/2011(1.3-04 a).pdf

[2] Abed Al-Arazzq, Omar (2002),"The Structure of Palestinian public budget”, Palestine Economic Policy Research Institute, Ramallah - Palestine.

[3] Abu-Zaiter, Ahmed (2012), "The Role of the local resources in financing the Palestinians Government Budget: Suggestions to strengthen the local resources role in financing the budget deficit (2000-2010)", Master Thesis, Al Azhar University Gaza, Palestine.

[4] Agrawal, Amol (2011), "India in Twin Deficit Club Implications and Issues", STCI Primary Dealer Ltd. http://www.stcipd.com/UserFiles/File/India\%20in\%20Twin\% 20Deficit\%20Club\%20\%20Implications\%20and\%20Issues.pd $\mathrm{f}$

[5] Akbar Zamanzadeh, and Mohsen Mehrara (2011), "Testing Twin Deficits Hypothesis in Iran", Interdisciplinary Journal of Research in Business, Volume: 1, Issue: 9, P. 7-11, http://www.idjrb.com/articlepdf/idjrb9n1p2.pdf

[6] Ali Abbas, Jacques Bouhga-Hagbe, Antonio J. Fatás, Paolo Mauro, and Ricardo C. Velloso, (2011), "Fiscal Policy and the Current Account", International Monetary Fund, http://www.imf.org/external/np/seminars/eng/2010/eui/pdf/AB H.pdf

[7] Barro, Robert (1989), "The Ricardian Approach to budget Deficits", Journal of Economic Perspectives, Volume 3, Issue 2, P. 37-54, American Economic Association, USA.

[8] Ebrahim Merza, Mohammad Alawin, and Ala' Bashayreh (2012), " The Relationship between Current Account and Government Budget Balance: The Case of Kuwait ", International Journal of Humanities and Social Science, USA,

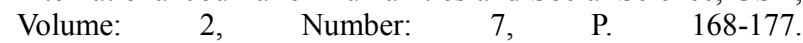
http://www.ijhssnet.com/journals/Vol_2_No_7_April_2012/19 .pdf.

[9] International Monetary Fund (2009), "Balance of Payments And International Investment Position Manual ", $6^{\text {th }}$ Edition, The International Monetary Fund Statistics Department's, International Monetary Fund, Publication Services Washington, D.C., USA.

[10] Kswani, Mamdouh Alkhatib (2001), "Budget and Current Account Deficits In Saudi Arabia", Economics Studies, Suadi Economic Assosiation, King Saud University, Saudi Arabia.

[11] M. Maitah, A. der Ali (2010), " Analysis of the Relationship between the Public Budget and Balance of Trade in the Libyan Economy from 2000-2008", AGRIS on-line Papers in Economics and Informatics, Publisher: Czech University of Life Sciences, Czech Republic, Volume: 2, Issue: 4, P. 35-49. $\mathrm{http}: / /$ online.agris.cz/files/2010/agris_on-line_2010_4_special _maitah_der-ali.pdf

[12] Magazzino, Cosimo (2012), " Fiscal Policy, Consumption and Current Account in the European Countries", Economics
Bulletin, Volume: 32, Number: 2, P. 1330-1344, http://www.accessecon.com/Pubs/EB/2012/Volume32/EB-12V32-I2-P127.pdf

[13] Mahmoud El-Jafari, and Naser Al-Ardah (2002), "The Impact of Palestinian Trade and Fiscal Policies on Trade and Budget Deficits ", Palestine Economic Policy Research Institute, Palestine. www.mas.ps/2012/sites/default/files/budget2.pdf

[14] Marinheiro, Carlos Fonseca (2008), "Ricardian Equivalence, Twin Deficits, and the Feldstein-Horioka puzzle in Egypt", Journal of Policy Modeling, Elsevier, Volume: 30, Issue: 6, P. 1041-1056.

http://gemf.fe.uc.pt/workingpapers/pdf/2006/gemf06_07.pdf

[15] Metri F. Mdanat, and Manhal M. Shotar (2009), "Budget Deficit and Jordan's Current Account Deficit: An Empirical Study 1977-2008", Journal of Engineering and Computer Sciences, Volume: 25, Issue: 2, P. 19-43, http://jeas.cbe.uaeu.ac.ae/jeas2009-Dec/2_Budget_Mdnat_A.p df

[16] Mohsen Bahmani and Oskooee, "Effects of the US Government Budget on its Current Account", Quarterly Review of Economics and Business, Vol. 29(4), Winter 1989, pp:76-91.

[17] Neaime, Simon (2008), "Twin Deficits in Lebanon: A Time Series Analysis", American University of Beirut, Institute of Financial Economics Working Paper Series No. 2, 2008. http://www.aub.edu.lb/fas/ife/Documents/downloads/series\%2 02_2008.pdf

[18] Rudiger Dornbusch and Stanley Fischer (1994), "Macroeconomics", $6^{\text {th }}$ Edition, McGraw-Hill.

[19] Saleh, M. Mohsen (2011), "The Palestinian Strategic Report 2010", Al-Zaytouna Center for Studies and Consultations, Beirut, Lebanon.

[20] Palestinian Central Bureau of Statistics, Major National Accounts Variables for the Years 1994-2011 at Constant Prices: 2004 is the Base Year. http://www.pcbs.gov.ps/Portals/_Rainbow/Documents/MajorC onstantE1994-2011.htm

[21] Palestine Economic Policy Research Institute (MAS) (2008), "Economic and Social Monitor: Volume 12", Palestine Economic Policy Research Institute, Ramallah - Palestine. http://www.pma.ps/images/stories/economic_monitor/arabic-d ocuments/monitor_12\%20-\%20ar.pdf

[22] Palestine Economic Policy Research Institute (MAS) (2013), "Economic and Social Monitor: Volume 31", Palestine Economic Policy Research Institute, Ramallah - Palestine. http://www.mas.ps/2012/sites/default/files/Monitor\%2031\%20 Arabic.pdf

[23] Palestine Economic Policy Research Institute (MAS) (2012), "Round Table Discussion (2): The Palestinian National Authority's Budget, 2012 "Palestine Economic Policy Research Institute, Ramallah - Palestine. http://www.mas.ps/2012/sites/default/files/Round\%20Table\% 202-PA\%20Budget\%20.pdf

[24] Palestine Monetary Authority (2003), "Annual Report 2002", Palestine Monetary Authority, Research and Monetary Policy Department, Ramallah - $\quad$ Palestine. http://www.pma.ps/images/stories/pdfs/english\%20summary\%202002 .pdf 
[25] Palestine Monetary Authority (2010), "Annual Report 2009", Palestine Monetary Authority, Research and Monetary Policy Department, Ramallah - Palestine. http://www.pma.ps/images/stories/pdfs/annual\%20report\%202 009.pdf

[26] Palestine Monetary Authority (2012), "Revenues, Expenditures and Financing Sources of PNA Fiscal Operations (Cash Basis)", Palestine Monetary Authority, Research and Monetary Policy Department, Ramallah - Palestine

[27] Vyshnyak, Olga (2000), "Twin Deficit Hypothesis: Th Case of Ukraine", Master Thesis, Kyiv-Mohyla Academy, National University, Kyiv, Ukraine.
[28] Palestinian Central Bureau of Statistics web site http://www.pcbs.gov.ps/

[29] Palestinian Monetary Authority web site http://www.pma.ps/

[30] Palestinian National Authority-Ministry of Finance web site http://www.portal.pmof.ps/

[31] Palestine Economic Policy Research Institute (MAS) web site http://www.mas.ps/

[32] International Monetary Fund web site http://www.imf.org/ 